\title{
László Ervin, professzor emeritus, a Budapest Klub elnöke
}

DOI 10.35402/kek.2021.2.7

\section{Tíz meglátás (felismerés)}

1. A végső valóság, amelyet emberileg föl tudunk fogni, a kozmosz: a végtelen és örök lét szférája.

2. A kozmosz lényege egy végtelen és örök intelligencia léte.

3. Azzal az egyedülálló jelenséggel, amelyet ősrobbanásként (big bangként) ismerünk, a kozmosz a változás és fejlődés véges birodalmát alkotta meg: az univerzumot.

4. Az az intelligencia, amely a kozmosz lényege, alakítja az univerzum valamennyi elemét és folyamatát.

5. Az univerzumnak a kozmosz által történő alakítása olyan jelenségeket teremt, amelyek - részlegesen - felfoghatók az emberi intellektus számára. A felfogható jelenségek rezgések olyan csoportjai, amelyeket az emberi megfigyelő anyagi struktúrákként és az elme elemeiként érzékel.

6. Azok a jelenségek, amelyek anyagi struktúrákként és az elme elemeiként nyilvánulnak meg, fejlődnek az univerzumban. $\mathrm{Ez}$ a fejlődés nem véletlenszerü, hanem célirányos. Az anyagi jelenségek fejlődési iránya az, hogy koherens rendszereket hozzanak létre. Azoknak a jelenségeknek a fejlődési iránya, amelyek az elme elemeinek megnyilᄀvá-nulásai, az azon jelenségek egy-ségének a felismerése, amelyek az univerzumban fejlődnek.

7. Az anyagi struktúrák (jelenségeinek) és az elme-elemek (jelenségeinek) fejlődése kölcsönösen segítik egymást: a koherens rendszerek jelenségei hozzájárulnak a velük kapcsolatos elme fejlődéséhez. hasonlóképpen az elme-jelenségek fejlődése irányt szab a rendszereken (és jelenségeiken) belüli és azok közötti fejlődésnek, és elősegítik azt.

8. A koherens rendszerek befogadják és megtestesítik az őket alakító kozmikus intelligenciát, és ezáltal térben és időben továbbítják (szétsugározzák) ezen intelligencia elemeit. Az elme jelenségei, amelyek a koherens rendszerek jelenségeivel együtt fejlődnek, részesülnek a koz $\neg$ mikus intelligenciából, és továbbít $\neg$ ják ennek az intelligenciának az elemeit az elme holografikus töredékeihez, amelyek a koherens rendszerekkel együtt fejlődnek.

9. A kozmosz intelligenciájának átvitele az univerzumba az univerzumban lévő anyag és az elme jelenségeinek alapvető célja.

10. A végső célja annak, hogy a kozmosz intelligenciáját koherens rendszerek és az elme holografikus fragmentumai átvigyék az univerzumba, a velük kapcsolatban lévő koherens rendszerek (jelenségeinek) és az elme (jelenségeinek) a kozmosz végtelen létével való eggyé válása.

\section{Zehn Einblicke}

1. Die letzte Wirklichkeit, die wir menschlich begreifen können, ist der Kosmos: eine Sphäre des unendlichen und ewigen Wesens.

2. Das Wesen des Kosmos ist das Sein einer unendlichen und ewigen Intelligenz.

3. Mit der Einzigartigkeit, die wir als den Urknall kennen, hat der Kosmos eine endliche Domäne von Veränderung und Entwicklung geschaffen: das Universum.

4. Die Intelligenz, die der Kosmos ist, bildet alle Dinge und Prozesse im Universum.

5. Die Information des Universums durch den Kosmos schafft Phänomene, die für die menschliche Intelligenz (teilweise) verständlich sind. Die verständlichen Phänomene sind integrale Cluster von Vibrationen, die menschlichen Beobachtern als Strukturen von Materie und Elementen des Geistes erscheinen.

6. Phänomene, die Strukturen der Materie und Elemente des Geistes offenbaren, entwickeln sich im Universum. Diese Entwicklung ist nicht zufällig und orientiert. Die Orientierung der Evolution von Phänomenen der Materie ist die Schaffung von kohärenten Systemen. Die Orientierung der Phänomene, die Elemente des Geistes offenbaren, ist die Anerkennung 
der Einheit der Phänomene, die sich im Universum entwickeln.

7. Die Evolution von (Phänomenen) von Strukturen der Materie und (Phänomene von) Elementen des Geistes ist wechselseitig zugänglich: kohärente Systemphänomene ermöglichen die Evolution des mit ihnen verbundenen Geistes; Und entwickelte Geist-Phänomen-Führer und erleichtern die Entwicklung der Kohärenz in und unter den (Phänomenen von) Systemen.

8. Kohärente Systemphänomene empfangen und verkörpern die kosmische Intelligenz, die sie in Form bringt und damit Elemente dieser Intelligenz in Raum und Zeit überträgt. Die Phänomene des Geistes, die sich in Verbindung mit kohärenten Systemphänomenen entwickeln, erhalten die kosmische Intelligenz und überträgt Elemente dieser Intelligenz auf die holographischen Fragmente des Geistes, die sich in Verbindung mit kohärenten Systemen entwickeln.

9. Die Übertragung der Intelligenz des Kosmos in das Universum ist das Ziel, das dem Vorhandensein von Phänomenen von Materie und Geist im Universum zugrunde liegt.

10. Das endgültige Ziel der Übertragung der Intelligenz des Kosmos in das Universum durch kohärente Systeme und holographische Fragmente des Geistes ist der Aufstieg der (Phänomene) kohärenten Systeme und der mit ihnen verbundenen (Phänomene) Geist in die Gemeinschaft mit Das unendliche Wesen des Kosmos.

\section{Ten Insights}

1. The ultimate reality we can humanly conceive is the cosmos: a sphere of infinite and eternal being.

2. The being of the cosmos is the being of an infinite and eternal intelligence.

3. With the singularity we know as the Big Bang, the cosmos created a finite domain of change and development: the universe.

4. The intelligence that is the cosmos in-forms all things and processes in the universe.

5. The in-formation of the universe by the cosmos creates phenomena that are (partially) comprehensible to human intelligence. The comprehensible phenomena are integral clusters of vibration that appear to human observers as structures of matter and elements of mind.

6. Phenomena that disclose structures of matter and elements of mind evolve in the universe. This evolution is nonrandom and oriented. The orientation of the evolution of phenomena of matter is toward the creation of coherent systems. The orientation of phenomena that disclose elements of mind is toward recognition of the oneness of the phenomena that evolve in the universe.

7. The evolution of (phenomena of) structures of matter and (phenomena of) elements of mind is reciprocally enabling: coherent systems phenomena enable the evolution of the mind associated with them; and evolved mind-phenomena guide and facilitate the evolution of coherence in and among the (phenomena of) systems.

8. Coherent systems phenomena receive and embody the cosmic intelligence that in-forms them, and thereby transmit elements of that intelligence into space and time. The phenomena of mind that evolves in association with coherent systems phenomena receives the cosmic intelligence, and transmits elements of that intelligence to the holographic fragments of mind that evolve in association with coherent systems.

9. The transmission of the intelligence of the cosmos into the universe is the objective underlying the presence of phenomena of matter and mind in the universe.

10. The ultimate objective of the transmission of the intelligence of the cosmos into the universe by coherent systems and holographic fragments of mind is the ascent of the (phenomena of) coherent systems and of the (phenomena of) mind associated with them into communion with the infinite being of the cosmos. 